\title{
Effects of hormone treatments, season, age and type of mares on ovulation, twinning and pregnancy rates of mares inseminated with fresh and frozen semen
}

\author{
Terttu Katila \\ University of Helsinki, Department of Clinical Veterinary Sciences, Saari Unit, Mäntsälä, Finland
}

\begin{abstract}
Summary
Records of a stud farm from years 1988-2000 consisting of 1085 mares and 1908 cycles were analyzed in a retrospective study. The type of semen had a significant effect $(p<0.001$ ) on pregnancy rate/cycle (fresh semen Al on the stud farm $56.1 \%$, shipped semen $51.7 \%$ and frozen semen $33.1 \%$ ) but not on ovulation and twinning rates. From all cycles, $11.0 \%$ were double ovulations, and ovulation rate was significantly increased by PG-treatment (prostaglandin), but not by hCG-treatment (human chorionic gonadotropin). However, hormone treatments had no effect on twinning rate (overall 6.1\%) or on pregnancy rate. Double ovulations increased twinning rate significantly $(p<0.001)$ and decreased pregnancy rate $(p<0.05)$. The time interval between PG-injection and Al affected ovulation rate $(p<0.001)$. Double ovulations increased from day 8 onwards, but this was not reflected in the twinning rate. Inseminating mares after ovulation did not change ovulation or twinning rates but decreased pregnancy rates. Mare category had no effect on twinning or pregnancy rate, but foaling mares had less double ovulations. Pregnancy rate/cycle of mares inseminated in the 1st p.p. (post partum) oestrus was lower than that of mares inseminated in the 2 nd p.p. oestrus. The month of Al had an effect on ovulation rate ( $p=0.037)$, highest double ovulation rates occurred in late summer.
\end{abstract}

Keywords: ovulation rate, twins, pregnancy rate, prostaglandin, frozen semen

Auswirkungen von Hormonbehandlungen, Saison, Alter und Reproduktionsstatus auf Ovulation, Zwillingsträchtigkeits- und Trächtigkeitsraten von Stuten inseminiert mit frischem und gefrorenem Samen

In einer retrospektiven Studie wurden Aufzeichnungen eines Gestütes über 1085 Stuten und 1908 Zyklusverläufe aus den Jahren 1988 2000 untersucht. Die Art des verwendeten Samens zur instrumentellen Samenübertragung (KB) hatte einen signifikanten Einfluss ( $p<0,001)$ auf die Trächtigkeitsrate pro Zyklus (56,1\% frischer Samen gewonnen auf dem Gestüt, 51,7 \% zugekaufter frischer Samen und 33,1\% gefrorener Samen), jedoch wurden die Ovulations- oder Zwillingsträchtigkeitsraten nicht beeinträchtigt. In $11 \%$ aller untersuchter Zyklen kamen Doppelovulationen vor. Es konnte eine signifikante Erhöhung der Ovulationsrate durch Prostaglandin -Substitution (PG) festgestellt werden, dagegen wurde durch eine hCG-Substitution (human chorionic gonadotropin) kein Effekt erzielt. Eine Auswirkung von Hormonbehandlungen auf die Zwillingsträchtigkeitsrate (insgesamt 6,1\%) oder die Trächtigkeitsrate lag nicht vor. Doppelovulationen erhöhten die Zwillingsträchtigkeitsrate signifikant $(p<0,001)$ und verminderten die Trächtigkeitsrate $(p<0,05)$. Das Zeitintervall zwischen PG-Substitution und KB beeinflusste die Ovulationsrate $(p<0,001)$ direkt. Trotz der Tatsache, dass Doppelovulationen bei Insemination ab dem achten Tag nach PG-Substitution vermehrt auftraten, konnte kein Einfluss auf die Zwillingsträchtigkeitsrate festgestellt werden. Wurde die KB nach erfolgter Ovulation vorgenommen, nahmen die Trächtigkeitsraten ab, währenddessen die Ovulations- und Zwillingsträchtigkeitsraten unverändert blieben. Der Reproduktionsstatus der Stuten innerhalb der Studie hatte keinen Effekt auf Zwillingsträchtigkeits- oder Trächtigkeitsraten, Fohlen führende Stuten jedoch zeigten weniger Doppelovulationen. Stuten, die im ersten Östrus p.p. (post partum) besamt wurden, wiesen eine geringere Trächtigkeitsrate pro Zyklus auf als Tiere, die im zweiten Östrus p.p. inseminiert wurden. Einen weiteren Einfluss auf die Ovulationsrate stellte der Monat der KB dar ( $p=0,037)$ : Die höchsten Doppelovulationsraten traten im Spätsommer auf.

Schlüsselwörter: Reproduktion, Ovulationsrate, Zwillingsträchtigkeit, Trächtigkeitsrate, Prostaglandin, Tiefgefriersperma

\section{Introduction}

Use of prostaglandins (PG) and human chorionic gonadotropin (hCG) has become common practice in equine stud farm medicine. The popularity of fresh shipped semen Al (artificial insemination) and frozen semen $\mathrm{Al}$ has increased the need to time ovulations resulting in more frequent use of hCG. Prostaglandin treatments are commonly used to induce oestrus in mares with silent heat or persistent corpus luteum. Although both hormones are valuable tools and contribute towards earlier foalings and increased foaling rates, there has been some concern that they might decrease conception rate (Voss et al. 1979, Lindeberg et al. 2002) and increase twin- ning rate. In Newmarket, U.K., the twin pregnancy rate rose from $2.1 \%$ in 1982/83 to $6.8 \%$ in 1998. (Morris and Allen 2001). This increase is likely to have many causes. Diagnosis and veterinary management have improved, but the increased use of hormones may also have contributed to this change.

In a retrospective study, results of mares treated with PG only, hCG only, PG and hCG-combination and not treated with any hormones were compared. Some additional factors possibly influencing ovulation, pregnancy and twinning rates were also analyzed. 


\section{Materials and methods}

In this retrospective study, records of a stud farm from years 1988-2000 consisting of 1085 mares and 1908 cycles were analyzed. The mares were inseminated in $1-7$ cycles: 1 cycle $53 \%, 2$ cycles $28 \%, 3$ cycles $12 \%$, and $4-7$ cycles $7 \%$. The mares were American Standardbreds (46\%), riding horses of different breeds (37\%), Finnhorses (15\%), and ponies (2\%). Based on previous reproductive history, the mares were divided into foaling (39\%), maiden (30\%), barren (13\%), and rested mares that had foaled but had not been bred subsequently (18\%). Because numerous stallions had been used and the number of mares/stallion was small, the stallion effect was not analyzed. Instead, the effects of different types of semen were included: frozen semen, shipped fresh semen and semen collected from the stallion resident on the same stud farm as the mare. The mares were almost equally distributed into these three semen groups: $37 \%$ frozen semen $\mathrm{Al}$, $33 \%$ transported semen $\mathrm{Al}$ and $32 \%$ fresh semen $\mathrm{Al}$. Almost all frozen semen was imported, mostly from Sweden and Germany. Shipped fresh semen originated from Finnish stallions (Standardbreds and Finnhorses), but a substantial number of Standardbred mares were inseminated with semen from stallions resident in Sweden, and almost all riding horse mares were inseminated with semen imported from Sweden and Germany. The transport time was usually 8-20 hours.

All mares were examined with transrectal ultrasonography for ovarian and pregnancy status. The time interval between examinations varied from several days to $8 \mathrm{~h}$ depending on the status of the mare and the type of semen used. The dose of hCG was $3.000 \mathrm{IU}$ in the early years, but it was later reduced to $1.500 \mathrm{IU}$ intravenously, and it was usually given when the mare had a $4-\mathrm{cm}$ follicle. Different PG-preparations were used during the years, but the majority of mares had received $0.25-0.125 \mathrm{mg}$ of cloprostenol intramuscularly. The stage of the cycle during PG-administration was not always known, but in most cases PG was given to mares with an ultrasonically detectable corpus luteum. The hormone treatments were distributed as follows: PG + hCG 11\%, PG only 12\%, hCG only $31 \%$, and no hormone treatments $46 \%$ of the mares. The age and type of the mare, time of foaling, Al, PG- and hCGtreatments and the size of the largest follicle at the time of PG and hCG administration and Al were recorded. The effect of preovulatory vs postovulatory $\mathrm{Al}$ on ovulation and pregnancy

Tab 1 Effect of different types of semen on double ovulation rate, pregnancy rate per cycle and twinning rate. Number of mares and percentage are given. $\mathrm{P}<0.001$ for pregnancy rate, other differences are not significant.

Einfluss verschiedener Samenarten auf die Doppelovulationsrate, die Trächtigkeitsrate pro Zyklus und die Zwillingsträchtigkeitsrate. Die Anzahl der Stuten und Prozentsätze sind angegeben.

\begin{tabular}{lccc} 
Type of semen & Double ovulation rate & Pregnancy rate & Twinning rate \\
\hline Fresh semen Al & 72 & 314 & 21 \\
in the stud farm & $12.9 \%$ & $56.1 \%$ & $6.7 \%$ \\
$\mathrm{n}=560$ & & & \\
& & 319 & 24 \\
Fresh semen Al & 71 & $51.7 \%$ & $7.5 \%$ \\
with shipped semen & $11.5 \%$ & & \\
$\mathrm{n}=618$ & & 237 & 8 \\
& 79 & $33.1 \%$ & $3.4 \%$ \\
Frozen semen Al & $11.0 \%$ & 870 & 53 \\
$\mathrm{n}=716$ & & $46.0 \%$ & $6.1 \%$ \\
Total & 222 & & \\
$\mathrm{n}=1894$ & $11.7 \%$ &
\end{tabular}

rates was compared. The effect of double ovulation rate on twinning and pregnancy rates was analyzed. The statistical analysis was carried out using Pearson Chi-Square test and Fisher's exact test. Since the type of semen had a significant effect on pregnancy rate per cycle, the data was analyzed first within each sperm category and then for the whole material.

\section{Results}

The overall pregnancy rate per cycle was $46 \%$ and it was significantly $(p<0.001)$ affected by the type of semen but not ovulation and twinning rates (Tab. 1).

From all cycles, $11.0 \%$ were double ovulations, and this was significantly increased by the PG-treatment ( $p=0.003$ ), but not by the hCG-treatment (Tab. 2). However, hormone treatments had no effect on the twinning rate (overall 6.1\%). The effect on the pregnancy rate/cycle was not statistically significant, although hCG-treatment resulted in highest pregnancy

Tab 2 Effect of hormone treatments on double ovulation rate, pregnancy rate per cycle and twinning rate. Number of mares and percentage are given. $P G=$ prostaglandin, $h C G=$ human chorionic gonadotropin. $\mathrm{P}=0.03$ for double ovulation rate, other differences are not significant.

Einfluss der Hormonbehandlung auf die Doppelovulationsrate, die Trächtigkeitsrate pro Zyklus und die Zwillingsträchtigkeitsrate. Die Anzahl der Stuten und Prozentsätze sind angegeben. PG = Prostaglandin, hCG = human chorionic gonadotropin

$\begin{array}{llcc}\text { Hormone treatment_Double ovulation rate } & \text { Pregnancy rate } & \text { Twinning rate } \\ \text { PG } & 38 & 114 & 9 \\ n=235 & 16.2 \% & 48.7 \% & 7.9 \% \\ \text { hCG } & 63 & 282 & \\ n=589 & 10.7 \% & 47.9 \% & 22 \\ \text { PG }+ \text { hCG } & 35 & 114 & 7.8 \% \\ n=203 & 17.2 \% & 48.7 \% & 5 \\ \text { No hormones } & 86 & 380 & 5.2 \% \\ n=871 & 9.9 \% & 43.6 \% & 17 \\ \text { Total } & 222 & 873 & 4.5 \% \\ n=1898 & 11.7 \% & 46.0 \% & 53 \\ & & & 6.1 \%\end{array}$

rates in the frozen and shipped semen groups. Double ovulations increased twinning rate significantly $(p<0.001)$ and decreased pregnancy rate $(p<0.05)$. The cycles were further analyzed for the time interval between PG-injection and Al by dividing the mares into those inseminated $<4,4,5,6,7,8$, 9,10 and $>10 \mathrm{~d}$ from PG-administration. This had a significant effect on ovulation rate $(p<0.001)$ increasing the number of double ovulations from day 8 onwards. This was not reflected to the twinning or pregnancy rate. The size of the largest follicle at the time of PG-injection had no effect.

Inseminating mares after ovulation (36.2\% of the cycles, the majority in the frozen semen group) did not change ovulation or twinning rate, but decreased pregnancy rates when mares were inseminated with fresh semen on the stud farm (before ovulation $59.5 \%$, after ovulation $32.4 \%$; $p<0.001$ ) and with frozen semen ( $40.2 \%$ vs $30.6 \% ; p=0.019)$.

The breed of the mare had no effect on ovulation, pregnancy and twinning rate. Foaling mares had less double ovulations than other types of mares $(p<0.001)$, but the mare category had no effect on the twinning rate or on the total pregnancy rate/cycle (Tab. 3). Mares with foal were further divided 
Tab 3 Effect of the type of the mare on double ovulation rate, pregnancy rate per cycle and twinning rate. Number of mares and percentage are given. $\mathrm{P}<0.001$ for ovulation rate, other differences are not significant.

Einfluss der Gruppenzugehörigkeit der Stuten innerhalb der Studie auf die Doppelovulationsrate, die Trächtigkeitsrate pro Zyklus und die Zwillingsträchtigkeitsrate. Die Anzahl der Stuten und Prozentsätze sind angegeben

\begin{tabular}{lccc} 
Type of the mare & Double ovulation rate & Pregnancy rate & Twinning rate \\
\hline $\begin{array}{l}\text { Foaling mares } \\
\mathrm{n}=720\end{array}$ & 48 & 348 & 13 \\
& $6.7 \%$ & $48.4 \%$ & $3.7 \%$ \\
Maiden mares & 81 & 254 & 19 \\
$\mathrm{n}=585$ & $13.8 \%$ & $43.4 \%$ & $7.5 \%$ \\
& & 156 & 12 \\
Barren mares & 57 & $46.3 \%$ & $7.7 \%$ \\
$\mathrm{n}=337$ & $16.9 \%$ & 113 & \\
& & $44.5 \%$ & $8.0 \%$ \\
Mares not bred & 36 & & \\
after previous & $14.2 \%$ & & \\
foaling & & 871 & 53 \\
$\mathrm{n}=254$ & & $46.0 \%$ & $6.1 \%$ \\
Total & 222 & & \\
$\mathrm{n}=1896$ & $11.7 \%$ & &
\end{tabular}

into mares inseminated $<20 \mathrm{~d}$ and $\Delta 20 \mathrm{~d}$ post partum (p.p.). Although mares in the $1^{\text {st }}$ p.p. oestrus showed less double ovulations $(4.4 \%)$ than mares inseminated in the $2^{\text {nd }}$ p.p oestrus (7.0\%), the difference was not significant, but there was a significant difference $(p=0.038)$ in the pregnancy rate (1st p.p. oestrus 40.3\%, 2nd p.p.oestrus 49.7\%). The mares were divided also into 3 age classes: $<8 y(n=537)$, 8 -16y $(n=1079)$ and $>16 y(n=262)$. The age had no significant effect on twinning or ovulation rate, but in the fresh semen $\mathrm{Al}$ group a high age tended to lower pregnancy rates (<8y $58.3 \%$, 8-16y 58.7\%, > 16y $46.2 \%$; $p=0.054$ ).

The month of $\mathrm{Al}$ had a significant effect on ovulation rate ( $\mathrm{p}$ $=0.037$ ); highest double ovulation rates occurred in August $(16.5 \%)$ and in September (26.1\%). When inseminations were grouped into those taking place before or after June the 1 st, the season exerted an effect on pregnancy rate per cycle in the shipped semen group $159.1 \%$ early in the season and $49.0 \%$ later). An opposite effect was seen in the frozen semen group: $28.4 \%$ in spring and $35.1 \%$ in summer. Although highest twinning rates were found in April (9.4\%) and in May (8.2\%) and lowest in August (3.7\%), the months did not differ significantly from each other.

\section{Discussion}

In this retrospective study, hCG did not increase ovulation rate, but PG did. No increase in twinning rate was observed which may be explained by the low number of twins. On the other hand, double ovulations increased the risk of twin pregnancies. In a larger material the effect on twinning might be more obvious. The ability to reduce twin pregnancies in horses to singletons increases the chances of mares prone to double ovulations and twin pregnancies to get live offspring. Because these are heritable characteristics (Ginther 1982), the occurrence of multiple ovulations and pregnancies is likely to increase. Frequent use of PG may contribute to the increase in double ovulation rate.

When mares were inseminated $\Delta 8$ days after PG-administration, the likelihood of double ovulation increased significantly in our study. Samper et al. (1993) administered clo- prostenol to mares on day 6 or 10 after ovulation, and they did not observe any effect on ovulation or conception rate as compared to saline controls. The mares injected on day 6 ovulated in average $8.2 \pm 1.6$ days later and the mares injected on day 10 ovulated $7.6 \pm 2.8$ days after the injection. The size of the follicle at the time of PG-administration affected the time interval to ovulation (Samper et al. 1993), but follicle size did not increase double ovulation rate in our retrospective study.

It is well known that pregnancy rates after frozen semen inseminations are lower than after fresh semen $\mathrm{Al}$, which was also confirmed in this study. The low overall pregnancy rate of $46 \%$ is explained by the large proportion of frozen semen use, which gave a total per cycle pregnancy rate of only $33.1 \%$. The quality of frozen semen doses varied a lot, and it is very likely that semen quality was more important than mare quality in the outcome of frozen semen $\mathrm{Al}$, which confounds results of this study. The pregnancy rate of $51.7 \%$ in the shipped semen group can be considered satisfactory.

Administration of hCG has been shown to result in high conception rates (Michel et al. 1986), and also in this study hCG-treatment seemed to be beneficial when mares were inseminated with shipped or frozen semen. Viability of the preserved sperm is compromised, and therefore, insemination close to ovulation becomes critical. Per cycle pregnancy rates were lower after postovulatory $\mathrm{Al}$ than after preovulatory Al. This suggests that when using frozen semen it is better to use hCG and time Al accordingly than to examine mares frequently and inseminate after ovulation. Although postovulatory Al can be successful when using fresh semen (Koskinen et al. 1990), frozen-thawed sperm may not be equally capable of fertilizing an aged ovum (Katila et al. 1996). The low per cycle pregnancy rate in the group of mares inseminated with fresh semen after detected ovulation on the same stud farm with the stallion can be explained by inseminations of late coming mares having already ovulated at the arrival. Although the corpus hemorrhagicum or luteum felt fresh on transrectal palpation, the actual time of ovulation was not known in these mares.

There are conflicting reports on the effect of month or season on ovulation rate (Ginther 1982). In p.p. mares, double ovulation rate was lower in January-March than in April-May (Loy 1980). Climatic and lighting conditions and the time of breeding season in Finland are somewhat different from those in southern countries. However, the month of $\mathrm{Al}$ exerted a significant effect: double ovulation rates were highest in AugustSeptember. In U.K., the breeding season of thoroughbreds is February-June, so only a few mares are bred in July. However, the twin ovulation rate was highest in July (Morris and Allen 2001). Numerically highest twinning rates in Finland, on the other hand, were found in April-May and lowest in August, but these differences were not significant. Also Morris and Allen (2001) detected highest twin pregnancy rates during early season in February and lowest in May and July. In the present study the seasonal effect on pregnancy rate was not the same in the different semen groups. When mares were inseminated with transported semen the pregnancy rate/cycle before June $1^{\text {st }}$ was $10 \%$ higher than after June $1^{\text {st }}$. Of course, the most fertile mares conceive early and problems mares are left at the end of the season. An opposite 
seasonal difference was detected in the frozen semen group. Again, there may be some other factors involved, i.e. at the end of the season, some problematic mares or mares inseminated with low quality frozen semen were transferred to a stallion from which fresh semen was available.

We demonstrated that foaling mares had less double ovulations than other types of mares. This has been shown earlier by Ginther (1982) and by Pascoe et al. (1986). In the material of Morris and Allen (2001), foaling mares had significantly less multiple ovulations (12\%) than barren, aborted or rested mares (20-23\%), but the maiden mares were not different from foaling mares. The incidence of multiple ovulations has been shown to be reduced $<80$ days p.p. (Ginther 1982). We set the limit to 20 days p.p. and also discovered a tendency for lowered double ovulations early post partum. Foaling mares had highest pregnancy rates in all groups (61.3\% fresh, $52.7 \%$ shipped and $36.5 \%$ frozen). The rested mares had the lowest pregnancy rates: fresh semen $47.0 \%$ and frozen semen $28.8 \%$, but the figures did not differ statistically.

Similarly to Ginther (1982), we did not see any age effect in the ovulation rate. However, Davies et al. (1999) and Morris and Allen (2001) found the multiple ovulation rate to increase with age. Decreased fertility of aged mares is generally acknowledged. In the present study, mares >16y had lower pregnancy rates when inseminated with shipped semen than younger mares. This effect was probably obscured in the frozen semen group by selection against mares with high age combined with bad reproductive history. In Thoroughbreds using natural cover, pregnancy rates of mares $\Delta 14 y$ were significantly lowered as compared to mares $£ 13 y$ (Morris and Allen 2001).

The breed - American Standardbred, Finnhorse and riding horses - had no effect in our study. Thoroughbreds have been shown have the highest frequency of multiple ovulations and ponies the lowest (Ginther 1982). Only a few individuals of these breeds were included in our material. Morris and Allen reported a $14.3 \%$ double ovulation rate in Thoroughbreds, which is $3 \%$ higher than double ovulation rate in our material.

It is concluded that the incidence of double ovulations was increased by the use of PG and particularly when mares were inseminated $\Delta 8 \mathrm{~d}$ after the injection. The double ovulation rate was decreased in foaling mares and particularly during foal heat; also early season tended to decrease the ovulation rate. Double ovulations were found to increase the risk of twinning. Factors decreasing per cycle pregnancy rates were use of frozen semen, postovulatory insemination, double ovulation, high age of the mare and $\mathrm{Al}$ in foal heat.

\section{Literature}

Davies Morel M. C. G. and O'Sullivan J. (1999): Ovulation rate and distribution in the Thoroughbred mare: the effect of mare age. J. Reprod. Fertil. 23, Abstract \#99, 39

Ginther O. J. (1982): Twinning in mares: A review of recent studies. J. Equine vet. Sci. 2, 127-135

Katila T., Celebi M. and Koskinen E. (1996): Effect of timing of frozen semen insemination on pregnancy rate in mares. Acta vet. Scand. 37, 361-365

Koskinen E., Lindeberg H., Kuntsi H., Ruotsalainen L. and Katila T. (1990): Fertility of mares after postovulatory insemination. J. Vet. Med. A 37, 77-80

Lindeberg H., Koskinen E., Huhtinen M., Reilas T., Perttula H. and Katila T. (2002): Influence of PG administration and follicle status on the number of conceptuses. Theriogenology 58, 571-574

Loy R. G. (1980): Characteristics of postpartum reproduction in mares. Vet. Clinics N.A. 2, 345-359

Michel T. H., Rossdale P. D. and Cash R. S. G. (1986): Efficiency of human chorionic gonadotropin and gonadotropin releasing hormone for hastening ovulation in Thoroughbred mares. Equine Vet. J. 18, 438-442

Morris L. H. A. and Allen W. R. (2001): Reproductive efficiency of intensively managed thoroughbred mares in Newmarket. Pferdeheilkunde 17, 548-556

Pascoe R. R., Pascoe D. R. and Wilson M. C. (1986): Influence of follicular status on twinning rate in mares. J. Reprod. Fertil., Suppl. 35, 183-189

Samper J. C., Geertsema H. P. and Hearn P. (1993): Rate of luteolysis, folliculogenesis and interval to ovulation in mares treated with a prostaglandin analogue on day 6 or 10 of the estrous cycle. 39th Ann. Conv. Am. Ass. Equine Practitioners, 169-170

Voss J. L., Wallace R. A., Squires E. L., Pickett B. W. and Shideler R. K. (1979): Effects of synchronization and frequency of insemination on fertility. J. Reprod. Fertil., Suppl. 27, 257-261

Prof. Terttu Katila

University of Helsinki

Faculty of Veterinary Medicine

Department of Clinical Veterinary Sciences, Saari Unit

Mäntsälä, Finland

terttu.katila@helsinki.fi 